\title{
On the Trifoliolate and other Leaves of the Gorse (Ulex europaeus, L.).
}

\section{A. BOODLE.}

T $\mathrm{N}$ seedlings of gorse the axis usually bears a certain number of trifolio1 late leaves after the cotyledons, and before the simple leaves. Of the simple leaves those first formed are nearly always flat, while the later ones are normally spiniform. ${ }^{1}$ The production of trifoliolate leaves is to be regarded as an ancestral character.

In a natural habitat the number of trifoliolate leaves may vary considerably, even among seedlings growing close together. Individual diversity with respect to this character is thus suggested, but it seemed probable that experiments would reveal some degree of plasticity. In order to gain some information on the subject, seedlings were grown on sand, and others on a mixture of loam, sand, and leaf-mould. When the seedlings had advanced far enough, ${ }^{2}$ they were examined, and the result compared for the two kinds of soil. The result appears to be worth recording, but further experiments require to be carried out in a different way, as indicated by some unsatisfactory features in the present experiment.

Remarks on some characters of the seedlings must now be made. Bifoliolate leaves occur, but are not so numerous as trifoliolate leaves. One or more of them are often produced as a transition from trifoliolate to simple leaves, and vice versa. The seedlings show great diversity as regards their leaves. A few bear simple leaves only, while others produce trifoliolate leaves in various numbers from one up to twenty or more. Then again the trifoliolate leaves may be variously distributed. They may begin directly after the cotyledons, and form an uninterrupted series succeeded by the simple leaves. Or the series of trifoliolate leaves may be preceded, and also interrupted once or many times, by simple and bifoliolate leaves.

Among the flat leaves two-lobed or three-lobed (or more deeply divided) leaves are occasionally present. These as well as the bifoliolate leaves may be regarded as showing an 'attempt' to realize the ancestral

1 Goebel : Organography of Plants (Engl. ed.), vol. i, p. I68.

2 Most of the plants were left until they had produced several spiniform leaves; it might then be assumed that no further trifoliolate leaves would be formed.

[Annals of Botany, Vol. XXVIII. No. CXI. July, 1914.] 
trifoliolate type. Hence these are included in the countings, and for convenience the bi- and trifoliolate and lobed leaves will be spoken of together as compound leaves. Among the apparently simple leaves some have an articulation at a distance from the base. This again is an indication of a compound nature, and these leaves would also have been counted with the trifoliolate leaves, but the presence of the articulation was overlooked until many of the plants had been examined and thrown away. Thus one type of approach to the trifoliolate condition has been ignored, but it appears probable that the nature of the result has not been thereby altered.

The experiment was started at the end of March, I9I3, when seeds were sown in two boxes of soil, composed of loam, sand, and leaf-mould, and in four boxes of sand, two of the latter being kept drier than the others during part of the experiment. The first examination of seedlings was made in the middle of July. It was then found that, though there was a good crop of seedlings, spiny above, others were still young, and some seeds were only just beginning to germinate. The backward seedlings, which were much more numerous in the cultures on sand, were examined later at intervals when they had progressed far enough. When the experiment was stopped at the beginning of September, some seeds were again just germinating, but the experience gained by that time appeared to show that the rest of the plants could be discarded without altering the direction of the result. ${ }^{1}$

The main result of the experiment is that seedlings of gorse grown on good soil, under the conditions of the experiment, produce a somewhat larger average number of compound leaves than those grown on sand. The seedlings on soil gave an average of 10.79 compound leaves per plant, while those on sand gave an average of 8.27 ; the difference $\left(2.5^{2}\right)$ amounts to about 23 per cent.

The number of seedlings examined was 2,895 , of which $\mathrm{I}, 094$ were on soil, and I,80I on sand. In counting the leaves, the different boxes were dealt with separately. The values for the average number of compound leaves given by the two boxes of soil came out very close, namely 10.73 and 10.87 . The figures for the boxes of sand were 8.60 and 8.43 for the two drier boxes, and 8.49 and $7.5 \mathrm{I}$ for the two damper boxes.

The conclusion appears to be justified, that in this case the presentation of an ancestral character is influenced to some extent by the nature of the soil, though at the same time there is great independent diversity in respect of this character.

The very backward seedlings which were not included in the countings from the boxes of soil were comparatively few, and would not have greatly

1 See below, p. 529. The soil and sand used in the experiment were not sterilized. Roottubercles were present on some seedlings. The effect of these would probably be to slightly diminish the difference in nutrition on the two kinds of soil. 
affected the average. Those omitted in the boxes of sand were more numerous, but, had they been included, they would no doubt have somewhat increased the average difference between soil and sand, as the later countings (i. e. of backward seedlings) on sand gave low values for the number of compound leaves.

In considering the result that the ancestral character is more pronounced on good soil, the suggestion may be made that this is a case of an ancestral character being favoured by ancestral soil conditions, since the gorse plant may be supposed to be descended from a plant with trifoliolate leaves, and having normal habitats among richer soil than that usually frequented by gorse. Other hypotheses expressed in terms of response to different physical factors might be attempted, but the above point of view should not be lost sight of, and may prove to have some theoretical importance. ${ }^{1}$

Lothelier ${ }^{2}$ carried out some experiments in which, when gorse was grown in an atmosphere saturated with moisture, the spiny character of the plant disappeared, and the leaves became flat. Wollny, ${ }^{3}$ however, found that only 12.5 per cent. of the plants of gorse with which he experimented gave the reaction described by Lothelier. Thus variation as regards plasticity has been recorded in gorse plants.

It is quite possible that there may be also differences in plasticity as regards the number of compound leaves produced by the seedlings, some of the latter being more easily influenced by soil conditions than others. If this is so, the leaf characters of a seedling may be thought of, for the sake of clearness, in relation to theoretical normal conditions (as giving a fixed point). Then when conditions are other than normal, the actual number of compound leaves formed by a given seedling may be regarded as determined by three factors, viz. (a) the number of compound leaves that would be produced by this individual under normal conditions; $(b)$ the degree of plasticity of this seedling; $(c)$ the deviation from normal conditions.

For comparison with the result obtained with gorse seedlings, reference may be made to an experiment carried out some years ago on the garden wallfower. ${ }^{4}$ In this case a presumably ancestral character was recognized in the three-armed hairs found on the early leaves of the seedling. These hairs were more numerous on seedlings grown on sand than on those grown on loam. ${ }^{5}$ Thus the ancestral character is here more pronounced on poor

1 See F. Darwin, Presidential Address, British Association, Dublin Meeting, 1908.

2 Lothelier : Recherches sur les plantes à piquants. Revue Générale de Bot., vol. v, p. 5 I 9.

3 Wollny, as quoted by Goebel, Experimentelle Morphologie der Pflanzen (1908), p. 35.

4 Boodle: On the Occurrence of Different Types of Hair in the Wallfower. Ann. of Bot., vol. xxii, p. 7 I 4 .

5 Only forty seedlings were used in this experiment, so the result requires confirmation. Further experiments were begun, but were abandoned on account of the trying nature of extensive haircounting. 
530 Boodle.-The Trifoliolate and other Leaves of Gorse.

soil. This is the reverse of the result with gorse, but, as the wild form of the wallflower is more or less xerophytic (growing on rocks, sea-cliffs, \&c.), this again appears to be a case of an ancestral character being favoured by ancestral soil conditions.

More general theoretical considerations are not included in the present note, as the writer hopes to carry out further experiments, which should yield a better basis for the discussion of the subject.

Jodreli. LABORATORY, KeW. 


\section{$2 \mathrm{BHL}$ Biodiversity Heritage Library}

Boodle, Leonard Alfred. 1914. "On the trifoliolate and other leaves of the gorse (Ulex europaeus, L.)." Annals of botany 28, 527-530.

https://doi.org/10.1093/oxfordjournals.aob.a089519.

View This Item Online: https://www.biodiversitylibrary.org/item/236856

DOI: https://doi.org/10.1093/oxfordjournals.aob.a089519

Permalink: https://www.biodiversitylibrary.org/partpdf/320037.

\section{Holding Institution}

Smithsonian Libraries

\section{Sponsored by}

Biodiversity Heritage Library

\section{Copyright \& Reuse}

Copyright Status: Not in copyright. The BHL knows of no copyright restrictions on this item.

This document was created from content at the Biodiversity Heritage Library, the world's largest open access digital library for biodiversity literature and archives. Visit BHL at https://www.biodiversitylibrary.org. 